\begin{tabular}{||l||c|c||}
\hline Received 07.07.2021 & & JOTS \\
\hline \hline Accepted 19.07.2021 & Research Article & $5 / 2$ \\
\hline \hline Published 24.07.2021 & & $2021: 393-402$ \\
\hline
\end{tabular}

\title{
Reinterpretation of Ötükän Y1š Expression in Orkhon Inscriptions
}

\author{
Orhon Yazttlari'ndaki Ötükän Yiš İbaresinin Yeni Yorumu
}

\author{
Fatih ŞENGÜL ${ }^{*}$ \\ Kocaeli/Turkey \\ E-mail:sengulf@gmail.com
}

The name Ötükän is mentioned as the geographical place name in the Orkhon inscriptions and the Terhin (Taryat) and Šinä Usu Inscriptions. Apart from this, it is seen that the same place name is also mentioned in the form of Ötükän Yıš in the Orkhon Inscriptions. Until today, different ideas have been put forward about what the word Ötükän and Yı̌ mean. In this study, the word ötükän will be handled and explained in a different way, on the other hand, it will be shown for the first time that the word Y̌s has a different meaning over its Chuvash equivalent.

Key Words: Old Turkic inscriptions, Ötükän Yiš, Old Turkic, Chuvash, Finno-Ugric, Scythians, Huns.

\footnotetext{
ORCID ID: 0000-0003-0111-3579.
} 
In Old Turkic, especially in Orkhon inscriptions, Terhin (Taryat) and Šinä Usu inscriptions Ötükän is mentioned as geographical place name. (Klyashtorny, 1982: 339, 340, 341, 343; Tekin, 1983: 47; Klyashtornyj, 2008: 169, 171, 175; Aydın, 2007: 59). In addition to this, in Orkhon inscriptions, the expression of Ötükän Ylš $¥ \mathbb{P} \mathrm{H}^{\mathbf{H}} \mathbf{h} \mathbf{N}$ is also mentioned.

I think it would be useful to look at the explanation of the word Ötükän before going into the explanation of the word Yiš. Because the explanation of the word Ötükän will facilitate the explanation of the word Yıš.

Since the Orkhon Inscriptions were deciphered by the Danish linguist Thomsen, until now, all linguists have translated the word Yiš as 'forest, forested mountain'. In my personal opinion, all of them, including Thomsen, read this word incompletely and gave the same word an incomplete meaning. The word Yıš was used with this meaning in the old Turkic inscriptions, and it is also used in the form of Ötükän Yıš together with the word Ötükän. The same linguists interpreted the meaning of this phrase as 'Ötükän forest and mountain' and it is claimed that the mountain mentioned is the Khangai Mountain range (Barat, 2007: 17), as well as the Otgon Tenger Mountain in Mongolia (Aydın, 2007: 126270). In Divân-ı Lûgati't-Türk, the same Ötükän (اوتوكان) is mentioned as "the name of a place close to the Uyghur province and in the Tatar deserts" (Kaşgarlı Mahmut, 1998/I:138).

Ötükän Ylšda yeg idi yok ärmiş il tutsı kyer Ötükän Yıš ärmiş. El tutsı yer Ötükän Yıš ärmiş "There has never been a better (place) than the Ötükän (forested) mountain. The place which will be settled in is the Ötükän (forested) mountain"; [T]ürük [kag]an Ötükän [yl]ş olursar eltä [buy] yok 'If the Turkish khan sits on the Ötükän (forest) mountain, there will be no trouble in the country"; Ötükän Yı̌ olursar bängü el tuta olurtaçı sän "If you live in the Ötükän mountains, you will live forever as a state owner." (Malov, 1951: 27-28)

Above, I have included only three sentences in which the phrase Ötükän Yǐs is used in old Turkish inscriptions. I do not find it necessary to write the other sentences in inscription where the same expression is mentioned, one by one.

Although Hüseyin Namık Orkun accepts that Ötükän means 'forest', he says that this word is the government centre of the Köktürks, which is considered sacred by the Turks and where the Turkish khan sits (1994: 735). Gabain also 
believes that the name Ötükän is the name of a plateau and the state centre of the Köktürks (2007: 291). Pelliot associated the same nomenclature with the Mongolian word Itügän or Ätügän, meaning 'earth god' (1929: 219). It is also necessary to mention the name Yütügen, which the Yakuts use to name the world in their religious poems and which is related to the word Ötükän (Ksenefentov, 2011: 166).

Ötü, the first syllable of the word Ötükän, is none other than the word ötü meaning 'old', which seems to derive from the word öd which means 'time' in old Turkic and entered Hungarian as a loanword with the form ido' 'time' (Zolton, 1912: 85; Benkő, 1993: 600; Róna-Tas \& Berta, 2011: 437-40). The scholars who prepared the Etymological Dictionary of Altaic Languages showed the word ötükän to be related to the ötü and interpreted it with the meaning of 'Old Country'. (Starostin etc., 2003/II: 1068).

In fact, the preparers of the mentioned dictionary unconsciously provided the most logical explanation, but did not give any explanation as to what the syllable kän meant.

It is true that the syllable kän, which constitutes the second element of the Ötükän expression, means city (Aydemir, 2010: 214). The person who puts forward this view claims that the remaining first syllable ötü means "prayer, request, suppliance' (2010: 214). Unfortunately, it is impossible to accept this. Apart from this, it has also been claimed that the word Ötükän means 'gates' (Sebzecioğlu, 2015: 44-52) in terms of etymology. Such a view is away from being convincing.

In my opinion, Ötükän is a combination of the words ötü and kän and it means 'old, ancient city' and it is a name given by the Turks based on their ancestors' residence in Ötükän and its geography since the earliest times. This argument is corroborated by the fact that the word kän has been used since the era of the Huns, long before the Turks appeared on the stage of history with the name Turk, was shown in a paper (Şengül, 2020a: 95-96).

According to Chinese annuals, Hunnic word 龍城 lungcheng was the place where the Huns offered sacrifice to their ancestors and meant 'Dragon City' (Bemmann, 2011: 443; Durand-Guédy, 2013:7; Ssu-ma Ch'ien, 2011: 191, 264). 


\section{ग(৫)}

龍 lung, the first component of the mentioned Hunnic word, is preserved in the forms of Lu, Liu and Louin in Turkic mythology, and all three have the meaning of 'dragon' (Korkmaz, 2008: 107; Uno, 2014: 169; ). It is in the form Ulu 'dragon' in the Altai dialect (Naskali \& Duranl1, 1999: 193). The words Lu and Luu mean also ‘dragon' (Kara, 2009: 170) in Mongolian and Mongolian dialects.

The form 城 cheng, the second component of the word Lungcheng, is the equivalent of the word kän, which means the city in Old Turkic (Uzunkaya, 2014: 51), in the Huns' language. In the Kašgarî's dictionary, this word is referred to as the name given to 'each city in the eastern countries' (Kaşgarlı Mahmut, 1998/I: 339-340).

There is another linguistic evidence to confirm the fact that the word Cheng means 'city'. When the Chinese source speaks of the Huns, he uses the term 城郭 Ch'engguo which means 'inner and outer city walls or permanent residences' (Ssu-ma Ch'ien 2011: 240) in their language elsewhere. The same Hunnic word is also interpreted as the cities with rampart wall (Onat et al., 2004: 1).

Here, Ch'eng is clearly used in the sense of the city. The term 郭 guo, which seems to carry meanings of house or settlement and etc, matches hu 'vineyard and garden shed' (DS: 2441), huğ 'guard shack' (DS: 2441), huğu 'guard shack' (DS: 2441), hüğ 'arbor, storehouse' (DS: 2448), Kyrgyz kui 'tent' (Radloff, 1899/II: 888) and kü̈̆ 'vineyard and garden shed' (DS: 3026) and etc.

There is no the letter $<\mathrm{r}>$ in Chinese. So the original form of Hunnic word can be related to Uighur kirao 'nomadic accommodation' (Shaw, 2014: 159), kirö 'temple in Burkhanism faith' (Naskali et al., 2007: 246), Kyrgyz küärkö 'some kind of tent' (Radloff, 1899/II: 1458) and Chagatai kurya 'building built badly, shack and barrack' (Radloff, 1899/II: 941) and etc.

Contrary to popular belief, Turks have used the word kän since the Hun era. Linguists attribute the origin of this word in Turkic to Sogdian knoh (Clauson, 1972: 728; Levitskaya et al., 1997: 44; Nadalyayev et al., 1969: 290; Räsänen, 1969: 252). I will not argue here whether the Turkic word is of Sogdian origin. However, there is another fact that I can state about this subject, which is that the word 


\section{J(৫)}

kän also means 'uncultivated field' (DS: 2741) in Turkish apart from the meaning of city. The relationship between the Finnish word kenttä, which means 'land, area, etc.' and the Turkish words 'city and field' is clear. Adverbs of place used in Turkic dialects for example, Uighur käni 'where', its Turkish equivalent, hani 'where'. Again, Old Turkic kanl 'where' and kanta 'where', are related to the word kän. Again, as in the words kurgan 'kale, kurgan' and kurukan 'tent', the suffix \{$\mathrm{kAn}$, which gives the meaning of place to the word to which it is added in Turkic, is also related to the word kän, which means city. Therefore, more arguments are needed to confirm that the Finnish and Turkic words are of Sogdian origin.

It is true that the word Yiš means something like 'forest, forested mountain', but the phrase Ötükän Yıš in the example sentences above never means such a meaning. The main reason why the true meaning of the term Ötükän Ylš has not been revealed until today is that the equivalence of the word Yiš in the Chuvash dialect, which is the only surviving branch of the oldest Turkic today, has not been seen.

This equivalence was first mentioned in a study and the word Ylš was associated with the word hyla recorded as 'forested area' in the language of the Scythians by Herodotus in the 5th century BC and it was shown that this wooded area, mentioned by the Greek writer, was the point where the Vorskla River joins the Dnieper River (Şengül, 2020b: 40, 46, 47).

The word hyla 'woodland, forest' in the language of the Scythians has been the most perfectly preserved in Turkic dialects. New Uygur hola 'tree' (Öztunçer, 2006: 146), Azerbaijani kollu 'bush, forested', kol 'bush', kula 'wood' (Akdoğan, 1999: 537), kol 'forest' (DS: 2906), kol 'brushwood' (DS: 2907), hola 'sheltered parts of forest and wooded places' (1974:2396), Kyrgyz kolo 'fir timber' (Yudahin, 1998: 480), yula (gula < yula in Bashkir dialect) 'elm' (İnan, 1998: 443) and etc. The words above are the current equivalents of the Scythian word.

The word used for forest in Orkhon monuments is Ylš (Ergin, 2002: 123; Tekin, 2016: 60). It has been identified with Sumerian word giş 'wood, tree' (Tuna, 1997: 7; Gerey, 2005: 202) The name given to the beech tree, which has an important place in Turkic Mythology, is huş (İnan, 1998: 415). 
The first Turkic was an Oghuric dialect. Today, Chuvash dialect is the only representative of this language. All other Turkic communities are in Common Turkic dialect.

One of the most distinctive differences that distinguish this dialect from the remaining Turkic dialects is that the letter /ş/ in other dialects is replaced by the letter $/ 1 /$ and the letter $/ z /$ in place of the letter $/ r /$. This linguistic transition between the words hul [< huş, seems to be the original form of $Y_{l s}>$ Glş] and Hyla, namely the /ş/ /l/ transition, can be easily seen.

The Scythian word has been preserved as hulă 'stick, thin branch (tree, bush, etc), twig, sprout' (Bayram, 2002: 273) in Chuvash. Chuvash hulă is identical with Ylš in the Orkhun Inscriptions (Şengül, 2020b: 47). Now let's move on to the actual connection. If Ylš in the Orkhon inscriptions is equivalent to the Chuvash word хулӑ, this word is also equivalent to the Chuvash word xyлa/hula (Benzing, 1943: 24; Bayram 2002: 273) which means city. For this reason, the actual meaning of Ötükän Ylš is not 'Ötükän Forest' but Ötükän City. This is what linguists have not seen until now.

Collinder shows the Vogul equivalent of Finnish kylä 'village' as kül, kwäl 'house, dwelling' (1977: 109) and he associates Finnish kylä 'house, dwelling, village' with Volga Turkish kül, kil 'hof, gasthof', the Ottoman gil 'home', Yakut kulä 'entrance hall, vestibule, place in front of the house' and Tungusic külol 'hut' (1977: 157). The words hula 'stoned or wooded shack built in order to keep milk in tablelands' (1974: 2441), hullä 'shack built in tablelands temporarily' (1974: 2442) and Taranchi hōla 'yard, garth' (Radloff, 1899/II: 1794) must also be added to this list.

Collinder could not sense or see the connection between the Chuvash word хула meaning 'city' and the Finnish and Vogul words. Finnish and Vogul words are other equivalents of Yiš in Orkhon Inscriptions.

Now, in the light of what has been written so far, let's re-read the above statements in the Orkhon Inscriptions: Ötükän Yı̌śda yeg idi yok ärmiš. El tutsık yer Ötükän Yı̌ ärmiş "There was never a better (place) than the city/province of Ötükän. The place which will be settled in is the city/province of Ötükän"; [T]ürük [kag]an Ötükän [yl]ş olursar iltä [buy] yok "If the Turkish khan lives in the city/province of Ötükän, there will be no trouble in the country"; Ötükän Yı̌ 


\section{J(ఠ)}

olursar bängü el tuta olurtaçı sän "If you live in Ötükän city/province, you will live forever as a state owner".

Ötükän nomenclature in Ötükän Yı̌̌ pattern is a name given mainly because the ancestors of the Turks have inhabited ötükän and its surroundings since the earliest times. Our view that the component Yı̌̌ in the Ötükän Yıš pattern means 'city' is also proved by the fact that the kän syllable at the end of the word ötükän means city. Due to the fact that the ancestors of the Turks residing in the ötükän geography have inhabited that area since ancient times, they named it Ötükän, which means 'Old, Ancient City' and this name has turned into Ötükän as a naming and a special name representing a geography with certain borders over time. Turks used the term $Y$ š at the end of the word in order to give the meaning of province to this special nomenclature.

Today, we find an example that fits the Ötükän Yıš pattern exactly in the name of Eskişehir, one of the main cities of Turkey. Eskişehir, which is used as a proper name, means 'Old City', but when we want to give Eskişehir the meaning of province or city, we say Eskişehir province or Eskişehir City. Here, Yıš in the Ötükän Yı̌ pattern was a term used for the province and the city.

Sum up, Yıš in Orkhun inscriptions, which means 'forest and mountain' and is identical with Chuvash hula 'city', is the exact equivalent of the Scythian hyla 'woodland' and also carries a meaning such as city/province.

Herodotus in his story about the origin of the Scythians mentions an incident of the kind where Heracles came to Hyla 'Woodland while searching for mares (Herodotos, 2004: IV-9). It is both interesting and thought-provoking that the Father of History uses the term 'Woodland' for a single field in a geography like Ukraine, which has a very forested area. He also relates a story about life of Anacharsis, a Scythian philosopher and adds that he was killed while he performs religious ritual in 'woodland' in Scythia (Herodotos, 2004: IV-76).

I think the word Hyla in the Scythian language meant not only 'Woodland' but also 'city and settlement centre', but the Greek writer recorded only a forestlike meaning here. 


\section{1)}

\section{References}

Akdoğan, Y. (1999). Azerbaycan Türkçe'sinden Türkiye Türkçe'sine Büyük Sözlük. Beşir Yayınları.

Aydemir, A. (2010). Ötükän ve Ötükän Adı Üzerine. Türk Dünyası Araştırmaları, 94(187), 197222.

Aydın, E. (2007). Ötükän Adı ve Yeri Üzerine Düşünceler. Turkish Studies, 2(4), 1262-1270.

Aydın, E. (2007). Şine Usu Yazıtı. Karam Yayınları.

Barat, K. (2007). Some Thoughts on Ötükän. Journal of Old Turkic Studies, 2(2), 7-25.

Bayram, B. (2002). Çuvaş Türkçesi-Türkiye Türkçesi Sözlük. Tablet Yayınları.

Bemmann, J. (2011). Was the Center of the Xiongnu Empire in the Orkhon Valley?. In Ursula, B. \& Bryan, K. M. (Eds.), Xiongnu Archaeology Multidisciplinary Perspectives of the First Steppe Empire in Inner Asia (pp. 441-461). Rheinische Friedrich-Wilhelms-Universität Bonn.

Benkő, L. (1993). Etymologisches Wörterbuch des Ungarischen. Akadémiai Kiadó.

Benzing, J. (1943). Deutsch-tschuwaschisches Wörterverzeichnis nebst kurzem tschuwaschischen Sprachführer. Otto Stollberg.

Clauson, S. G. (1972). An Etymological Dictionary of Pre-Thirteenth-CenturyTurkish. Oxford University Press.

Collinder, B. (1977). Fenno-Ugric Vocabulary: An Etymological Dictionary of the Uralic Languages. Hermut Buske Verlag.

Durand-Guédy, D. (2013). Turko-Mongol Rulers, Cities and City Life. Brill.

Ergin, M. (2002). Orhun Abideleri. Boğaziçi Yayınları.

Gabain, A. von (2007). Eski Türkçenin Grameri. Çev. Akalın, M. Türk Dil Kurumu Yayınları.

Gerey, B. (2005). 5000 Yıllık Sümer-Türkmen Bağları. IQ Kültürsanat Yayıncılık.

Herodotos. (2004). Herodot Tarihi. Türkiye İş Bankası Yayınları.

İnan, A. (1998). Makaleler ve İncelemeler. Türk Tarih Kurumu Yayınları.

Kara, G. (2009). Dictionary of Sonom Gara's Erdeni-Yin Sang: A Middle Mongol Version of the Tibetan Sa Skya Legs Bshad. Mongol-English-Tibetan. Brill.

Kaşgarlı Mahmut (1998). Divân-ı Lûgati't-Türk I. Türk Dil Kurumu Yayınları.

Klyashtorny, S. (1982). The Terkhin Inscription. Acta Orientalia Scientiarum Hungaricae. 36(1), 335-366.

Klyashtornyj, S. G. (2008). The Terkhin Inscription. In Old Turkic Runic Texts and History of the Eurasian Steppe (pp. 165-196). Editura Academiei Române. 


\section{ग(ब)}

Korkmaz, E. (2008). Ansiklopedik Eski Türk İnançları ve Şamanizm Terimleri Sözlüğü. Anahtar Kitaplar.

Ksenefentov, G. V. (2011). Yakut Şamanlı̆̆ı. Kömen Yayınları.

Levitskaya, L. S. et al. (1997). Etimologicheskiy Slovar' Tyurkskikh Yazykov: Obshchetyurkskiye i Mezhtyurkskiye Osnovy na Bukvy "K", "K” (Tom 5). Yazyki Russkoy Kul'tury.

Malov, S. (1951). Pamyatniki Drevnetyurkskoy Pis'mennosti, Teksty i Issledovaniya. Akademii Nauk SSSR.

Nadelyayev, V. M. et al. (1969). Drevnetyurkskiy Slovar'. İzdatel'stvo "Nauka" Leningradskoye Otdeleniye Leningrad.

Naskali, E. G. \& Duranlı, M. (1999). Altayca-Türkçe Sözlük. Türk Dil Kurumu Yayınları.

Onat, A. et al. (2004). Han Hanedanliğı Tarihi: Hsiung-nu (Hun) Monografisi. Türk Tarih Kurumu Yayınları.

Orkun, H. N. (1994). Eski Türk Yazıtları. Türk Dil Kurumu Yayınları.

Öztunçer, Ö. (2006). Uygur Şiveleri Sözlüğü (A'dan Z’ye Kadar Transkripsiyonlu Metin). Çanakkale 18 Mart Üniversitesi, Sosyal Bilimler Enstitüsü. (Unpublished Master Thesis).

Pelliot, P. (1929). Neuf Notes sur des Questions d'Asie Centrale. T'oung Pao, 26, 201-265.

Radloff, W. (1899). Versuch eines Wörterbuches der Türk-Dialecte II. Tipografiya İmperatorskoy Akademii Nauk.

Räsänen, M. (1969). Versuch eines etymologischen Wörterbuchs der Türksprachen. SuomalaisUgrilainen seura.

Róna-Tas, A. \& Berta, Á. (2011). West Old Turkic: Turkic Loanwords in Hungarian I. Harrassowitz Verlag.

Sebzecioğlu, T. (2015). Ötükän Sözcüğünün Etimolojisi Üzerine Bir Sav: Geçitler ya da Ana Kap1. Sosyal Bilimler Dergisi, 2(2), 44-52.

Shaw, R. B. (2014). Kâşgar ve Yarkend Ağzı Sözlüğü. Çev. Yıldırım, F. Türk Dil Kurumu Yayınları.

Ssu-ma Ch'ien, (2011). The Grand Scribe's Records IX: The Memoirs of Han China/II. Indiana Unniversity Press.

Starostin, S. et al. (2003). Etymological Dictionary of the Altaic Languages I-III. E. J. Brill.

Şengül, F. (2020a). The Horse-Related Terms and Animal Names in the Language of the Xiongnus (Asian Huns). The Journal of Eurasian Turkic Studies, 4, 80-104.

Şengül, F. (2020b). The Language of the Farmer Scythians. The Journal of International Society of Language and Literature, 46, 31-62. 


\section{J曰)}

Tekin, T. (1983). The Tariat (Terkhin) Inscription. Acta Orientalia Academiae Scientiarum Hungaricae, 37(1), 43-68.

Tekin, T. (2016). Orhon Türkçesi Grameri. Türk Dili Kurumu Yayınları.

Tuna, O. N. (1997). Sümer ve Türk Dillerinin Tarihi İlgisi ile Türk Dili’nin Yaşı Meselesi. Türk Dil Kurumu Yayınları.

Türkiye'de Halk Ağzından Derleme Sözlüğü I-XII (1993). II. Baskı. Türk Dil Kurumu Yayınları. $(\rightarrow \mathrm{DS})$

Uno, H. (2014). Altay Panteonu/Mitler, Ritüeller, İnançlar ve Tanrllar. Doğu Kütüphanesi.

Uzunkaya, U. (2014). Uygur Sivil Belgelerinden Hareketle Uygurlarda Yerleşik Yaşam ve Bununla İlgili Söz Varlığına Dair. Türkbilig, 27, 41-58.

Yudahin, K. (1998). Kırgız Sözlüğü I-II. Türk Dil Kurumu Yayınları.

Zolton, G. (1912). Bulgarisch-Türkischen Lehnwörter in der Ungarischen Sprache. Société Finno-Ougrienne. 